\title{
Maternal weight gain adequacy is associated with newborn birth weight in gestational diabetes mellitus
}

\author{
Livia Silveira Mastella*, Leticia Schwerz Weinert, Vanessa Gnielka, Vânia Naomi Hirakata, \\ Maria Lúcia Rocha Oppermann, Sandra Pinho Silveiro, Angela de Azevedo Jacob Reichelt \\ From 20th Brazilian Diabetes Society Congress \\ Porto Alegre, Brazil. 11-18 November 2015
}

\section{Background}

Gestational diabetes mellitus (GDM) is diagnosed in up to $18 \%$ of Brazilian women and is commonly related to pre-gestational obesity; superimposed weight gain during pregnancy may adversely contribute to maternal and fetal outcomes.

\section{Objective}

To evaluate weight gain patterns in women with GDM and its relation to newborn birth weight.

\section{Materials and methods}

Cohort study including 362 GDM women classified according to their pre-gestational body mass index (BMI). Gestational weight gain (GWG) was considered insufficient, adequate or excessive based on the Institute of Medicine 2009 recommendations for each pre-pregnancy BMI class. Newborns were classified as large (LGA), appropriate (AGA) or small for gestational age (SGA) according to the Alexander curve.

\section{Results}

Total GWG was $10.1 \pm 7.5 \mathrm{~kg}$ (range: -8.0 to $36.3 \mathrm{~kg}$ ). Appropriate weight gain occurred in $25 \%$ of women, excessive in $37.5 \%$ and insufficient, in $37.5 \%$. Adverse maternal outcomes (cesarean section, hypertension and postpartum dysglycemia) were similar among groups, as were prematurity rates. Obese women with excessive GWG had higher rates of LGA when compared to the other groups ( $28 \%$ vs $8 \%$ (insufficient) vs $6 \%$ (adequate), $\mathrm{p}=0.003)$. SGA rates were higher in women with normal

\footnotetext{
* Correspondence: livia_mastella@yahoo.com.br Particular clinic, Porto Alegre, Brazil
}

(C) 2015 Mastella et al. This is an Open Access article distributed under the terms of the Creative Commons Attribution License (http:// creativecommons.org/licenses/by/4.0), which permits unrestricted use, distribution, and reproduction in any medium, provided the original work is properly cited. The Creative Commons Public Domain Dedication waiver (http://creativecommons.org/publicdomain/ zero/1.0/) applies to the data made available in this article, unless otherwise stated.

\section{and take full advantage of:}

- Convenient online submission

- Thorough peer review

- No space constraints or color figure charges

- Immediate publication on acceptance

- Inclusion in PubMed, CAS, Scopus and Google Scholar

- Research which is freely available for redistribution Submit your manuscript at
www.biomedcentral.com/submit C BioMed Central 